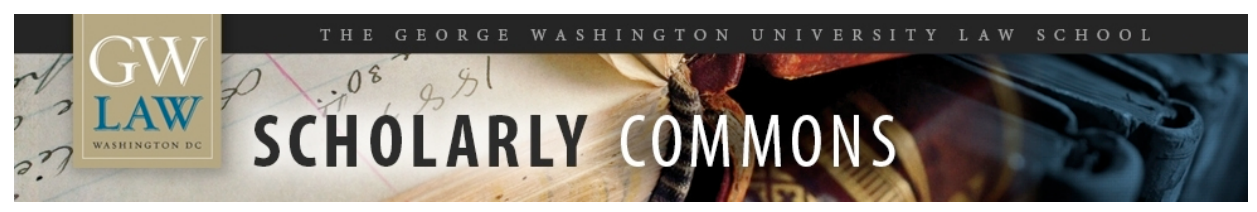

\title{
'Generational Theft'? Even with Stimulus and Bailout Spending, U.S. Fiscal Policy Does Not Cheat Future Generations
}

Neil H. Buchanan

George Washington University Law School, neilhbuchanan@gmail.com

Follow this and additional works at: https://scholarship.law.gwu.edu/faculty_publications

Part of the Law Commons

\section{Recommended Citation}

Neil H. Buchanan, 'Generational Theft'? Even with Stimulus and Bailout Spending, U.S. Fiscal Policy Does Not Cheat Future Generations, Challenge: The Magazine of Economic Affairs, May/June 2009.

This Article is brought to you for free and open access by the Faculty Scholarship at Scholarly Commons. It has been accepted for inclusion in GW Law Faculty Publications \& Other Works by an authorized administrator of Scholarly Commons. For more information, please contact spagel@law.gwu.edu. 
Do not cite or quote without written permission of the author.

Draft of March 5, 2009

Pre-published version. To be published in Challenge, May/June 2009

\title{
“Generational Theft"? Even With Stimulus and Bailout Spending, U.S. Fiscal Policy Does Not Cheat Future Generations
}

\author{
Neil H. Buchanan* \\ * Associate Professor, The George Washington University Law School; J.D, Ph.D. in economics; \\ nbuchanan@law.gwu.edu.
}




\section{Abstract:}

Despite the oft-heard claims that current generations are stealing from future generations by running fiscal deficits, both theory and evidence suggest that this is either not true or not knowable. Intergenerational justice is not an appropriate lens through which to analyze fiscal issues, because there is no obvious starting point from which to build a moral consensus about whether current generations owe anything at all to future generations - and even if we do believe that we owe something to future generations, no one has offered a useful method by which we can determine whether we are doing enough for our progeny. Moreover, if we believe that future generations should be made better off than current generations ("I want my kids to be richer than I am."), even pessimistic forecasts indicate that future generations will be much wealthier than current generations, meaning that we are already being quite generous to our children and grandchildren.

In addition, the recent significant decline in our economic prospects does not argue for a more contractionary fiscal policy in light of concerns about future generations. In fact, when times are bad, there is no conflict between the interests of current and future generations. Spending by the government helps to improve the economy, which encourages businesses to invest in future productivity. This virtuous cycle is even stronger if the government's spending is itself used to invest in future productivity. 
When the economy appears to be crumbling around us, should we change the way we think about present versus future needs? In a symposium that I organized in October 2008, the panelists (including a strong critic of current and projected levels of deficit spending) all agreed that the widely-held notion that current generations are being somehow unfair to future generations through profligate fiscal policy (especially the supposed problem of "runaway entitlements") is neither an accurate nor useful way to analyze fiscal policy. While there is reasonable disagreement about taxing and spending priorities, it is at least true that no one's arguments are advanced by suggesting that "we are cheating our grandchildren."

Events have a tendency to overtake scholarship, however, and the economic crisis that intensified in late 2008 and early 2009 has caused many analysts and commentators to reconsider their views on how the economy works and the appropriate government policies going forward. As it turns out, however, U.S. politicians' insistent use of the rhetoric of generational justice is even less meaningful in the current crisis. The interests of future generations and current generations are actually now in harmony rather than requiring tradeoffs.

The rhetoric of generational justice is, nevertheless, a staple of American politics. Every day, it seems, brings more examples of politicians and policy advocates justifying their arguments by referring to "our children and grandchildren." For example: 
"The biggest risk we Americans face to our way of life and our place in the world probably doesn't come from Al Qaeda or the Iraq war. Rather, the biggest risk may come from this administration's fiscal recklessness and the way this is putting us in hock to China. ... America's fiscal mess may be even harder to write about engagingly than Darfur, because the victims of our fiscal recklessness aren't weeping widows whose children were heaved onto bonfires. But if you need to visualize the victims, think of your child's face, or your grandchild's. President Bush has excoriated the 'death tax,' as he calls the estate tax. But his profligacy will leave every American child facing a 'birth tax' of about $\$ 150,000$. That's right: every American child arrives owing that much, partly to babies in China and Japan. No wonder babies cry." 1

Notwithstanding such overheated rhetoric, prior to the current crisis the prospects of at least the "average" members of future generations were quite good. Even under the most pessimistic long-term scenario (based on assumptions that imply historically anemic levels of economic growth for the next 75 years), the average income per capita of those Americans living in the ' 80 's (the 2080's, that is) would be comfortably more than twice current living standards. ${ }^{2}$ Under less pessimistic scenarios, those living 75 years from now would have average living standards that are more than triple or quadruple current living standards. ${ }^{3}$

Given the magnitude of those numerical forecasts, even allowing for significant errors makes it quite difficult to make the case that we are being unfair to future

\footnotetext{
$1 \quad$ Nicholas D. Kristof, “A Glide Path to Ruin,” N.Y. Times, Jun. 6, 2005, § 4 at 13.

2 Neil H. Buchanan, "What Do We Owe Future Generations?" 77 Geo. Wash. L. Rev. (2009), forthcoming. See also Neil H. Buchanan, "Social Security and Government Deficits: When Should We Worry?" 92 Cornell L Rev. 257, 266 n.57 (showing that government forecasts for 2080 have per capita GDP $131 \%$ higher than in 2005, under the most pessimistic scenario).

3 Id.
} 
generations. Even so, young voters are told that they are "being played for chumps" 4 and should thus "get angry [and] appeal to the shame and guilt of older Americans by reminding them that their present self-absorption is not a victimless exercise." ${ }^{5}$ Current adults are, we are being told again and again, being unfair to our progeny. We are supposedly a generation of selfish egoists, heedlessly ignoring our moral obligations to the young.

A sober analysis of intergenerational justice, however, does not merely rely on these extremely favorable forecasts of the living standards of future Americans. The deeper question is whether we can say with any certainty what our moral obligations are to future generations. Other than the vague hope that the future will be better than the present, however, no one has offered any useful way to determine how much better the future should be, nor for that matter do we have a good idea of why future generations of Americans deserve at least the level of material well-being available in 2009 rather than, say, 1959 or 1909 . Without a framework even to begin to discipline the analysis, the suggestion that current generations are self-interested boors is little more than a smoke screen to advance a favored policy agenda.

It is not as if the politicians and commentators have invented these concerns out of thin air, however. The author of the block quote above discussed at length the arguments being made by David Walker, the former Comptroller General of the United States. "'I think the greatest threat to our future is our fiscal irresponsibility,' warns David Walker, [who is] running around with his hair on fire, shrieking about America's

4 Robert J. Samuelson, "Young Voters, Get Mad," Wash. Post, Oct. 23, 2008, at A19. $5 \quad I d$. 
finances. Well, as much as any accountant ever shrieks." ${ }^{\prime 6}$ He also noted that the economist Joseph Stiglitz was "very worried" about the prospect of a financial crisis. ${ }^{7}$

In part, the analytical problem is with the infinite nature of "the future." When Walker says that fiscal irresponsibility is a threat to "our future," he could mean that there is likely to be a fiscal meltdown within the next five or ten years. Stiglitz's worry about a financial crisis is also not tied to a particular date or range of dates, but by nature anything that has not yet happened must happen (if at all) in the future. That (almost zenlike) observation muddies the debate, because it becomes unclear whether we are worried that one generation is being unfair to generations to be born in the future or instead that it is foolishly dooming itself to an impoverished immediate future. ${ }^{8}$ Indeed, one can be reasonably concerned about the prospects of a financial meltdown, even though there is no convincing case that current generations are being somehow unfair to future generations while we continue to coddle ourselves.

Some of the commentary from economists however, is anything but ambiguous about the current-versus-future generational conflict. N. Gregory Mankiw, a former advisor to President George W. Bush, celebrated his fiftieth birthday last year by offering a "birthday wish ... for all of us to ... focus on what we can do together to prepare the economy for our children and grandchildren, [so] that when I celebrate my 100th birthday

\footnotetext{
$6 \quad$ Nicholas D. Kristof, note 1 above, $\S 4$ at 13.

7 Id

$8 \quad$ Less ambiguously, Walker was also involved with the documentary film "I.O.U.S.A.” (2008), which purported to be the fiscal version of "An Inconvenient Truth" in warning about the immorality of intergenerational transfers.
} 
in 2058, my descendants won't look upon Grandpa and his generation as the biggest economic problem of their time." ${ }^{, 9}$ He noted in particular the costs of health care and other spending on current generations that will add to "the national debt we are passing on to future generations of taxpayers."

The economist who is perhaps the most vocal in claiming intergenerational unfairness, however, is Laurence Kotlikoff. Kotlikoff co-created the "generational accounts" framework favorably cited by some fiscal analysts. ${ }^{11}$ I (along with others) have critiqued Kotlikoff's work at length, ${ }^{12}$ showing that the assumptions and conclusions in the generational accounts literature are misleading at best. For example, the use of "lifetime net savings rates" to assess intergenerational fairness is unhelpful because such rates tell us nothing about the actual living standards of current and future generations. ${ }^{13}$

Kotlikoff has been absolutely clear that he is making a normative claim about intergenerational justice. For example, he has argued that "generational accounting indicates that if current and future generations do not step up to the plate, young and

9 N. Gregory Mankiw, "My Birthday Wish: Not Burdening Our Children,” N.Y. Times, Feb. 3, 2008, § BU at 6.

$10 \quad I d$.

11 Daniel Shaviro, "The Long-Term U.S. Fiscal Gap: Is the Main Problem Generational Inequity?” 77 Geo. Wash. L. Rev. (2009), forthcoming.

12 Neil H. Buchanan, "Social Security, Generational Justice, and Long-Term Deficits," 58 Tax L. Rev. 355 (2005).

13 Id. at 309. But see Shaviro, "Long-Term Fiscal Gap," note 11 above, at 18-22 (reporting on lifetime net tax rate computations). 
future generations will face lifetime net tax rates that are twice those of current adults. Attempting to foist such a burden on the next generation is not only immoral; it is also economically infeasible." 14 Kotlikoff, who has also warned of generational warfare and future political instability due to current fiscal policy, ${ }^{15}$ says that " $[\mathrm{t}]$ here is a limit to fiscal child abuse" and warns that the United States and other countries are "rapidly approaching that limit."16

It is, therefore, hardly the case that the professional economists have offered sober-minded technical analysis while editorialists and politicians have twisted their words into unrecognizable shrieks of panic. One cannot come away from Kotlikoff's writings without concluding that he believes that there is an intergenerational transfer being perpetrated by the current generations that is both harmful - "fiscal child abuse" and unfair.

To his credit, NYU law professor Daniel Shaviro has not engaged in this kind of over-the-top rhetoric. Instead, he has couched his remarks in the conditional tense appropriate to policy analysis: "Indeed, if one of the goals of reform is to reduce the financial burden on future generations by reducing the consumption (increasing the saving) of the current generation, then financing a gradual transition to personal accounts

\footnotetext{
14 Laurence J. Kotlikoff, “Paul Samuelson's Amazing Intergenerational Transfer,”in Samuelsonian Economics and the Twenty-First Century 48 (2006) (emphasis added).

15 Laurence J. Kotlikoff and Scott Burns, The Coming Generational Storm: What You Need to Know about America's Economic Future (2004).

$16 \quad$ Kotlikoff, note 14 above, at 48.
} 
through higher taxes or reduced spending is an effective way to achieve this goal."17

Professor Shaviro has on occasion, however, adopted a less neutral tone: "The Bush administration's policy of sharply cutting taxes while increasing government spending is both misguided and harmful. [I]t in fact increases the government's distributional intervention by handing money to current voters at the expense of younger and future generations." 18 Also: "This author has argued elsewhere that the impact of the current fiscal policy on future generations is unjustifiable." 19

Even so, Shaviro now agrees that the debate should not be about whether we are cheating future generations:

The chief harm, however, is not the one perhaps most frequently voiced - that of unfairly burdening future generations relative to current ones. The pervasive uncertainties that undermine efforts to specify an optimal policy of inter-generational distribution make it hard to conclude with any confidence that too many dollars are being shifted from them to us, rather than the right amount or too few. ${ }^{20}$

We should thus set aside the concern that current generations are being unfair to future generations, either because we view the likely inheritance of future generations already to be adequate or simply because we cannot agree on how to assess fairness or unfairness between generations. The state of the debate, therefore, now comes in two parts: first, whether the U.S. (even before the current economic crisis) was on an

17 Daniel N. Shaviro, "Reckless Disregard: The Bush Administration's Policy of Cutting Taxes in the Face of an Enormous Fiscal Gap," 45 B.C. L. Rev. 1285, 1333 (2004).

$18 \quad$ Id. at 1334.

19 Daniel N. Shaviro, “Accrual Accounting and the Fiscal Gap,” 1 Harv. J. on Legis. $209,214$.

$20 \quad$ Shaviro, "Long-Term Fiscal Gap," note 11 above, at 3. 
unsustainable path that should have been changed, and second, whether the new circumstances in which we find ourselves alter the debate. Regarding the first question, I have noted elsewhere the weaknesses in the forecasts of long-term fiscal unsustainability. ${ }^{21}$ For present purposes, there is no need to revisit that debate, although I will note that there is at the very least no reason to think that we need to balance the budget in the conventional sense of that term. ${ }^{22}$

The recession that began in December 2007 deepened in late 2008 and shows no sign of letting up in 2009. The first major initiative of the Obama administration was to propose and ultimately pass a stimulus bill that was officially estimated to total $\$ 787$ billion in spending and tax cuts. ${ }^{23}$ During the debate over the measure, opponents of the package tried to make an issue of the supposed intergenerational unfairness from adopting such a package. For example, the House minority leader, John Boehner, said: "Yes, our economy needs help. But at the end of the day, how much debt are we going to pile on future generations?"24 By the end of the debate, Republicans in the Senate were referring to the bill as "generational theft." 25

If there were no economic crisis and the government for some reason decided to pass a bill that increased spending and cut taxes, the result of that decision could be

\footnotetext{
21 Buchanan, "Long-Term Deficits," note 12 above, at 306-22.

$22 \quad$ Id. at 277 .

23 David M. Herszenhorn, "Recovery Bill Gets Final Approval," N.Y. Times, Feb. 13, 2009 , at A1.

24 Peter Baker and David M. Herszenhorn, "Senate Allies Fault Obama On Stimulus," N.Y. Times, Jan. 9, 2001, at A1.
}

25 Frank Rich, "They Sure Showed That Obama," N.Y. Times, Feb. 15, 2009, § WK at 10. 
analyzed in the usual ways, with the resulting increase in the deficit likely to result in lowered living standards in the future (relative to their already higher levels). This would, of course, still leave us without guidance as to whether such a transfer would be moral or immoral, but at least the nature of the transfer would be clear: when the economy is operating at or near full capacity, increasing the deficit will tend to lower future living standards by "crowding out" private investment and leaving future generations with smaller amounts of productive capital.

When the economy is in a serious downturn, however, the story becomes quite different. Crowding out is no longer relevant, because there are idle plants and workers, and the government is thus not competing with private actors for financing or for real resources as it puts in motion its spending projects. The major concern is to prevent idled resources from becoming unusable (both machinery falling into disrepair and people becoming physically and emotionally damaged by the consequences of unemployment) and to put the economy back on a path that will allow current generations to invest as much as they wish in future productivity.

Not only is there unlikely to be any crowding out of private investment by government deficits, but the evidence shows that government efforts to bring the economy out of recession creates a virtuous cycle by which more government spending leads to more private investment rather than less. "Crowding in," as it is called, applies directly to the situation that we currently face. ${ }^{26}$ The idea behind this theory is that businesses have no reason to build new factories or to buy more equipment when the

\footnotetext{
26 See Benjamin M. Friedman, "Crowding Out or Crowding In? Economic Consequences of Financing Government Deficits," Brookings Papers on Econ. Activity 593 (1978).
} 
economy is weak, because there are no customers to buy the goods that businesses are already producing. If the government changes the direction of the economy, however, the result is that businesses are encouraged to invest more in productive capital, which gives further momentum to the economy. ${ }^{27}$ Empirical estimates have shown that this effect can be quite powerful, and the effect is strongest on investment in equipment, which is one of the most productive types of private investment (and thus the most advantageous for future generations). ${ }^{28}$

In short, when the economy is weak, the case for government spending (that is, deficit-financed spending) becomes stronger not only for the good of current generations but for future generations as well. The stimulus encourages economic activity now, and that activity encourages firms to invest for the future. This benefit to future generations can be stronger still if the government spends its money on projects that are themselves likely to improve future living standards. Spending money to hire more teachers, to increase funding for basic research, to build advanced communications and transportation networks, and to upgrade existing infrastructure all put people back to work in the immediate term and create both human and physical capital that will benefit future generations. There is, again, no intergenerational conflict.

Imagine, however, that there really were a tradeoff between spending money now

27 Paul A. Samuelson, "Interactions between the Multiplier Analysis and the Principle of Acceleration," 21 Rev. Economics and Statistics 75 (1939).

28 Neil H. Buchanan, "The Effects of the Fiscal Deficit on the Composition of U.S. GDP: An Analysis of Disaggregated Data," in Paul Davidson and Jan A. Kregel, eds., Improving the Global Economy 133 (1997). 
to fight a recession (and to prevent it from becoming a depression) and the well-being of future generations. If we really had to decide whether to make our grandchildren poorer than they would otherwise be in order to stem the current crisis, how should we decide what to do? Because we cannot converse with those not yet born, we can at least ask ourselves what we would say if we had had the opportunity to talk with our grandparents and great-grandparents as they faced the Great Depression. We are much richer than they were, with living standards beyond anything that they could imagine. Even before the Depression began, per-capita income in1929 (adjusted for inflation in 2000 dollars) was just over $\$ 7000$, whereas today it is over $\$ 38,000 .^{29}$ If we could have done something more to prevent their average income from dropping in 1933 to just over $\$ 5000^{30}$ (over a $25 \%$ decline), would we?

If the answer to that question is even a qualified yes, then the current situation at least suggests that we could feel less guilty even if we thought that our actions to fight the downturn might make our grandchildren less rich than they will otherwise be.

Fortunately, because the government's stimulative actions both directly and indirectly will improve the outcomes for all generations, there is no need to wonder just how generous we might be in a similar situation.

\footnotetext{
29 U.S. Bureau of Economic Analysis, National Income and Product Accounts, Table 7.1. Selected Per Capita Product and Income Series in Current and Chained Dollars, http://bea.gov/national/nipaweb/TableView.asp?SelectedTable=253\&ViewSeries=NO\&Java=no\&Request3 Place $=$ N\&3Place $=$ N\&FromView $=$ YES\&Freq $=$ Year $\&$ FirstYear $=1929 \&$ LastYear $=2008 \& 3$ Place $=$ N\&AllYe arsChk $=$ YES\&Update $=$ Update $\&$ JavaBox $=$ no\#Mid

$30 \quad I d$.
} 
There are, of course, prudential reasons why we might want to change our fiscal policies, chief among which is the possibility that we are on an unsustainable path. While there is disagreement about the validity of the forecasts that make our current policies appear to be unsustainable, it is important to determine what is and is not responsible for long-term deficits. Notwithstanding the common claims about "greedy seniors," the problem is not Social Security, and the Medicare problem is not due to excess generosity toward older citizens but rather to unsustainable trends in health care costs overall.

\section{Conclusion}

Should the recent dramatic darkening of our economic situation cause us to be more concerned about the effects of deficit spending on the economic interests of future generations? Should the necessity of large fiscal stimulus bring forth concerns that fighting the recession will impoverish our children and grandchildren? The short and happy answer to these questions is no. Fighting the recession will encourage more private investment spending, not less. Moreover, if we fight the recession by engaging in public investment in education, research, and other forms of human and physical capital, we will make future generations richer still.

Even so, we might be doing some things that involve the equivalent of asking for help from our grandchildren. Fortunately, if we do the right things, our grandchildren will be rich enough to be more than happy that we were able to help ourselves emerge from the current crisis with their help. 